\title{
Yield and morphological attributes of bell pepper fruits under biological fertilizers and application times ${ }^{1}$
}

\author{
Ygor Henrique Leal ${ }^{2}$, Joana Gomes de Moura ${ }^{2}$, Toshik Iarley da Silva ${ }^{3 * *} \mathbb{D}$, Thiago Jardelino Dias ${ }^{2}$, \\ Márcia Paloma da Silva Leal ${ }^{2}$, João Everthon da Silva Ribeiro ${ }^{2}$
}

\author{
$10.1590 / 0034-737 X 202067050005$
}

\begin{abstract}
Bell pepper (Capsicum апnиит) is one of the most consumed vegetables around the world. Balanced fertilization is essential for growing this vegetable. The objective of this study was to evaluate the yield and morphological attributes of bell pepper under doses and times of application of biological fertilizers. Two experiments were carried out with applications of biological fertilizers prepared from manure and enriched organic compounds with cattle manure and sheep manure. The experimental design was a randomized complete block design, in a 4 × $3+1$ factorial scheme, with three replications, referring to doses of biological fertilizers $\left(100,200,300\right.$ and $\left.400 \mathrm{~L} \mathrm{ha}^{-1}\right)$, times of application $(0$, 30 and 60 days after transplanting - DAT) and control. The evaluated variables were: total fruit weight (TFW), number of commercial fruits (NCF), number of non-commercial fruits (NNCF), fruit weight ( $\mathrm{FW}$ ), fruit diameter (FD), fruit length (FL), resistance of fruit peel (RFP), number of flower buds (NFB) and productivity (P). Biological fertilizers caused positive effects on TFW, NCF, FW and P of bell pepper. The application of cattle manure at $60 \mathrm{DAT}$ and sheep manure at 30 DAT promoted a larger fruit diameter. The FW, FL and RFP were influenced by the doses and times of application of biological fertilizers. The application of biofertilizers is efficient in the production of bell pepper.
\end{abstract}

Keywords: biometry; Capsicum апnиит; organic fertilizer; plant nutrition; productivity

\section{INTRODUCTION}

The fruits of bell pepper (Capsicum annuиm L.) have a great diversity of shapes and flavors, being found in green, red, yellow, orange or purple, depending on the variety and maturity stage. They are widely used in the cooking of various regions of Brazil, being consumed unripe or ripe, however, the consumption of green fruits is predominant (Santos et al., 2013).

Changes in society's eating habits and concern for the environment are frequent, increasing the demands of the consumer market regarding the commercialization of foods that use less and less synthetic products in their production, making producers look for alternatives to meet this growing demand (Santos et al., 2018).

Intensive food production is usually accompanied by technology packages involving synthetic fertilizers and other agrochemicals to provide rapid and efficient responses to increased production. Linked to these inputs are the harms caused to the soil and plants, causing stress of crops and chemical overload of these environments, providing fall in productivity or even making it impossible to cultivate due to desertification, depending on the degree of severity (Bertollo et al., 2015).

Considering the increasing demand for food, the environmental problems facing society, the need for nutrient supply to the plants and the production costs, it is necessary to develop research in the agricultural sector that develops efficient alternatives that promote a common good among these factors, creating new perspectives of production (Chiconato et al., 2013).

The use of biological fertilizers or biofertilizers prepared with animal waste and other sources of nutrients and

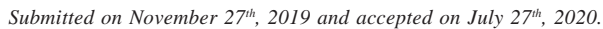

${ }^{1}$ Este trabalho é parte da tese de doutorado do primeiro autor.

${ }^{2}$ Universidade Federal da Paraíba, Centro de Ciências Agrárias, Areia, Paraíba, Brazil. ygoragronomo@gmail.com; joanagomes1963@hotmail.com; thiagojardelinodias@gmail.com; palomalealagro@gmail.com; j.everthon@hotmail.com

${ }^{3}$ Universidade Federal de Viçosa, Departamento de Fitotecnia, Viçosa, Minas Gerais, Brazil. iarley.toshik@gmail.com

*Corresponding author: iarley.toshik@gmail.com
}

Rev. Ceres, Viçosa, v. 67, n.5, p. 374-382, sep/oct, 2020 
microorganisms has been a promising alternative, improving the chemical, physical and biological characteristics of the soil, promoting higher crop yields, and reducing costs with mineral fertilizers (Guimarães et al., 2017).

Mineral fertilizers can be replaced by biofertilizers to meet the nutritional requirements of plants, promoting maximum growth and productivity; however, it is necessary to establish adequate doses (Celedonio et al., 2016). Thus, the present study aimed to evaluate the morphological attributes and yield of bell pepper under doses and times of application of biological fertilizers.

\section{MATERIALS AND METHODS}

\section{Description of the study site}

Two experiments were conducted simultaneously in a commercial cultivation area in the Perímetro Irrigado Apolônio Sales (Apolônio Sales Irrigated Perimeter), Petrolândia, Pernambuco. Located in Pernambuco Semiarid, on the banks of the São Francisco River. The climate according to the Köppen and Geiger classification is BSh type, characterized as warm semiarid (Parahyba et al., 2004; Alvares et al., 2014). A digital thermohygrometer and a pluviometer were installed to obtain daily data on temperature, relative humidity and rainfall (Figure 1).

\section{Experimental design}

Two biofertilizers were prepared, one biofertilizer with cattle manure and another biofertilizer with sheep manure. The experimental design was a randomized complete block in a factorial scheme $(4 \times 3+1)$, with three replications. The treatments were doses of biological fertilizers (100, 200, 300 and $400 \mathrm{~L} \mathrm{ha}^{-1}$ ), application times (0, 30 and 60 days after transplantation - DAT) and a control treatment (without application of biofertilizer).

As for application times, in treatments 1 to 4 the doses of biological fertilizers were applied in full on the day of transplantation (0 DAT). In treatments of 5 to 8 the doses were fractionated twice, at 0 and 30 DAT, and in the 9-12 treatments the doses were fractionated three times, with applications at 0, 30 and 60 DAT (Table 2).

\section{Plant material}

Seeds of peppers Solário hybrid was used. The seedlings were produced in 128-cell trays using commercial substrate. After 32 days after sowing, transplantation was performed with $1.5 \times 0.5 \mathrm{~m}$ spacing. 80 $\mathrm{kg} \mathrm{ha}^{-1}$ of urea was applied at five DAT, $130 \mathrm{~kg} \mathrm{ha}^{-1}$ of NPK (06-24-12) was applied at seven DAT and $260 \mathrm{~kg} \mathrm{ha}^{-1}$ of NPK (20-10-20) was applied at 37 DAT, as recommended for culture in the State of Pernambuco. The experimental plot consisted of four rows of four meters, corresponding to an area of $24 \mathrm{~m}^{2}$, with 32 plants. The usable area was 6 $\mathrm{m}^{2}$, consisting of the two central rows, eliminating two plants from the ends of each row, totaling 8 plants.

\section{Soil and Biofertilizers}

The soil was classified as an Oxisolic Quartzarenic Neossol (Santos et al., 2006). Even being installed parallel experiments a soil sample was collected from each area. The soil analysis of cattle manure was: $\mathrm{pH}\left(\mathrm{H}_{2} \mathrm{O}, 1: 2.5\right)=$ 6.95; $\mathrm{P}\left(\mathrm{mg} \mathrm{dm}^{-3}\right)=388.01 ; \mathrm{K}^{+}\left(\mathrm{mg} \mathrm{dm}^{-3}\right)=152.88 ; \mathrm{Na}^{+}$ $\left(\mathrm{cmol}_{\mathrm{c}} \mathrm{dm}^{-3}\right)=0.12 ; \mathrm{H}^{+}+\mathrm{Al}^{+3}\left(\mathrm{cmol}_{\mathrm{c}} \mathrm{dm}^{-3}\right)=3.47 ; \mathrm{Al}^{+3}\left(\mathrm{cmol}_{\mathrm{c}}\right.$ $\left.\mathrm{dm}^{-3}\right)=0.0 ; \mathrm{Ca}^{+2}\left(\mathrm{cmol}_{\mathrm{c}} \mathrm{dm}^{-3}\right)=3.50 ; \mathrm{Mg}^{+2}\left(\mathrm{cmol}_{\mathrm{c}} \mathrm{dm}^{-3}\right)=$ 1.50; sum of bases $\left(\mathrm{cmol}_{\mathrm{c}} \mathrm{dm}^{-3}\right)=5.51$; cation exchange capacity $\left(\mathrm{cmol}_{\mathrm{c}} \mathrm{dm}^{-3}\right)=8.98$; base saturation $(\%)=61.40$; aluminium saturation $(\%)=0.0$; organic matter $\left(\mathrm{g} \mathrm{kg}^{-1}\right)=$ 10.73; total organic carbon $\left(\mathrm{g} \mathrm{kg}^{-1}\right)=8.60$. The soil analysis of sheep manure was: $\mathrm{pH}\left(\mathrm{H}_{2} \mathrm{O}, 1: 2.5\right)=6.81 ; \mathrm{P}\left(\mathrm{mg} \mathrm{dm}^{-3}\right)=$ $497.50 ; \mathrm{K}^{+}\left(\mathrm{mg} \mathrm{dm}^{-3}\right)=155.22 ; \mathrm{Na}^{+}\left(\mathrm{cmol}_{\mathrm{c}} \mathrm{dm}^{-3}\right)=0.10$; $\mathrm{H}^{+}+\mathrm{Al}^{+3}\left(\mathrm{cmol}_{\mathrm{c}} \mathrm{dm}^{-3}\right)=3.14 ; \mathrm{Al}^{+3}\left(\mathrm{cmol}_{\mathrm{c}} \mathrm{dm}^{-3}\right)=0.0 ; \mathrm{Ca}^{+2}$ $\left(\mathrm{cmol}_{\mathrm{c}} \mathrm{dm}^{-3}\right)=3.50 ; \mathrm{Mg}^{+2}\left(\mathrm{cmol}_{\mathrm{c}} \mathrm{dm}^{-3}\right)=1.50$; sum of bases $\left(\mathrm{cmol}_{\mathrm{c}} \mathrm{dm}^{-3}\right)=5.10$; cation exchange capacity $\left(\mathrm{cmol}_{\mathrm{c}} \mathrm{dm}^{-3}\right)$ $=8.23$; base saturation $(\%)=61.92$; aluminium saturation $(\%)=0.0$; organic matter $\left(\mathrm{g} \mathrm{kg}^{-1}\right)=14.83$; total organic carbon $\left(\mathrm{g} \mathrm{kg}^{-1}\right)=6.23$.

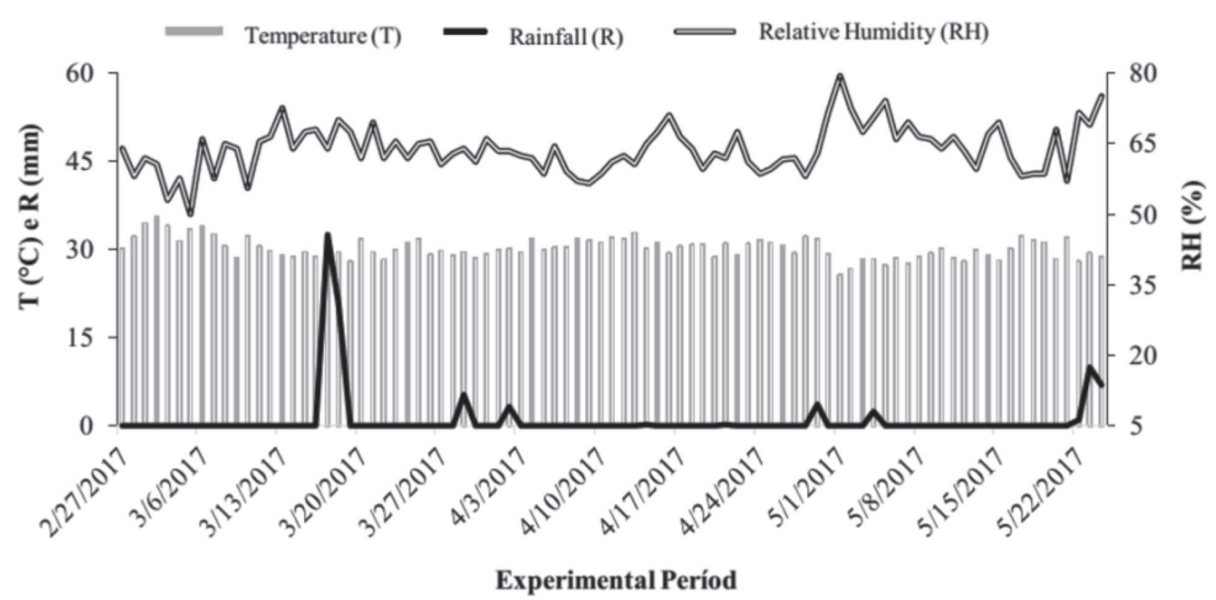

Figure 1: Temperature $(\mathrm{T})$, rainfall $(\mathrm{R})$ and relative humidity $(\mathrm{RH})$ of bell pepper area in the experimental period. 
The biological fertilizers were prepared according to the manufacturer's recommendations, using two biofactories (polyethylene water tanks) with a capacity of 100 liters. The biological fertilizers consisted of recalcitrant substances, biodynamic preparations, pentoses, minerals and bran (Microgeo, 2019).

Each biofactory was filled with five kilograms of enriched organic compound, 15 liters of manure (cattle or sheep) and 80 liters of water. Every three days the biological fertilizer was stirred and ready for use after 15 days of preparation (Microgeo, 2019). The application of biological fertilizers was performed on the soil surface, using a hand sprayer with a capacity of five liters, and the organic input was pre-filtered through a $2 \mathrm{~mm}$ mesh sieve.

Chemical analysis of biological fertilizers was performed. The analysis of cattle manure biofertilizer was: humidity
$(\%)=98.70 ;$ organic carbon $(\%)=10.40 ; \mathrm{N}\left(\mathrm{g} \mathrm{L}^{-1}\right)=0.10 ; \mathrm{P}$ $\left(\mathrm{g} \mathrm{L}^{-1}\right)=0.08 ; \mathrm{K}^{+}\left(\mathrm{g} \mathrm{L}^{-1}\right)=30.90 ; \mathrm{Ca}^{2+}\left(\mathrm{g} \mathrm{L}^{-1}\right)=0.22 ; \mathrm{Mg}^{2+}(\mathrm{g}$ $\left.\mathrm{L}^{-1}\right)=0.58 ; \mathrm{S}\left(\mathrm{g} \mathrm{L}^{-1}\right)=0.05 ; \mathrm{Na}\left(\mathrm{g} \mathrm{L}^{-1}\right)=0.00 ; \mathrm{Cu}\left(\mathrm{mg} \mathrm{L}^{-1}\right)=$ $0.43 ; \mathrm{Zn}\left(\mathrm{mg} \mathrm{L}^{-1}\right)=0.61 ; \mathrm{Fe}^{3+}\left(\mathrm{mg} \mathrm{L}^{-1}\right)=5.12 ; \mathrm{Mn}^{2+}\left(\mathrm{mg} \mathrm{L}^{-1}\right)$ $=0.62 ; \mathrm{B}\left(\mathrm{mg} \mathrm{L}^{-1}\right)=2.22$. The analysis of sheep manure biofertilizer was: humidity $(\%)=98.80$; organic carbon $(\%)$ $=11.10 ; \mathrm{N}\left(\mathrm{g} \mathrm{L}^{-1}\right)=0.11 ; \mathrm{P}\left(\mathrm{g} \mathrm{L}^{-1}\right)=0.07 ; \mathrm{K}^{+}\left(\mathrm{g} \mathrm{L}^{-1}\right)=24.30$; $\mathrm{Ca}^{2+}\left(\mathrm{g} \mathrm{L}^{-1}\right)=0.15 ; \mathrm{Mg}^{2+}\left(\mathrm{g} \mathrm{L}^{-1}\right)=0.27 ; \mathrm{S}\left(\mathrm{g} \mathrm{L}^{-1}\right)=0.07 ; \mathrm{Na}(\mathrm{g}$ $\left.\mathrm{L}^{-1}\right)=0.00 ; \mathrm{Cu}\left(\mathrm{mg} \mathrm{L}^{-1}\right)=0.46 ; \mathrm{Zn}\left(\mathrm{mg} \mathrm{L}^{-1}\right)=0.54 ; \mathrm{Fe}^{3+}(\mathrm{mg} \mathrm{L}$ $\left.{ }^{1}\right)=10.60 ; \mathrm{Mn}^{2+}\left(\mathrm{mg} \mathrm{L}^{-1}\right)=0.51 ; \mathrm{B}\left(\mathrm{mg} \mathrm{L}^{-1}\right)=2.13$.

Irrigation was performed by drip. The water came from the São Francisco River and the average daily-applied leaf was $9.12 \mathrm{~mm}$ per plant, split into two $4.56 \mathrm{~mm}$ applications, in the early morning and late afternoon. On days when there was sufficient rain, irrigation was suspended, supplementing when needed. Water analysis

Table 1. Summary of variance analysis of the variables evaluated in the first five bell pepper harvests under biological fertilizers, doses and application times

\begin{tabular}{lccccccccc}
\hline \multirow{2}{*}{ SV } & TFW & NCF & AFW & FD & FL & FPR & NNCF & NFB & P \\
\cline { 2 - 11 } & \multicolumn{7}{c}{ P value } \\
\hline Times (T) & $0.1679^{\text {ns }}$ & $0.2305^{\text {ns }}$ & $0.4097^{\text {ns }}$ & $0.0719^{\text {ns }}$ & $0.3779^{\text {ns }}$ & $0.5499^{\text {ns }}$ & $0.7348^{\text {ns }}$ & $0.8656^{\text {ns }}$ & $0.5383^{\text {ns }}$ \\
Dose (D) & $0.3913^{\text {ns }}$ & $0.2568^{\text {ns }}$ & $0.0902^{\text {ns }}$ & $0.028^{\text {ns }}$ & $0.4976^{\text {ns }}$ & $0.6256^{\text {ns }}$ & $0.4755^{\text {ns }}$ & $0.6609^{\text {ns }}$ & $0.6071^{\text {ns }}$ \\
Fertilizer (F) & $0.0097^{* *}$ & $0.0374^{*}$ & $0.0047^{* *}$ & $0.365^{\text {ns }}$ & $0.5495^{\text {ns }}$ & $0.4342^{\text {ns }}$ & $0.4893^{\text {ns }}$ & $0.0897^{\text {ns }}$ & $0.0114^{*}$ \\
T x D & $0.9778^{\text {ns }}$ & $0.8123^{\text {ns }}$ & $0.0504^{\text {ns }}$ & $0.025^{*}$ & $0.2639^{\text {ns }}$ & $0.4715^{\text {ns }}$ & $0.0533^{\text {ns }}$ & $0.3663^{\text {ns }}$ & $0.8057^{\text {ns }}$ \\
T x F & $0.5241^{\text {ns }}$ & $0.7532^{\text {ns }}$ & $0.0555^{\text {ns }}$ & $0.0022^{* *}$ & $0.5063^{\text {ns }}$ & $0.6575^{\text {ns }}$ & $0.0378^{*}$ & $0.6401^{\text {ns }}$ & $0.7283^{\text {ns }}$ \\
D x F & $0.8262^{\text {ns }}$ & $0.7246^{\text {ns }}$ & $0.8847^{\text {ns }}$ & $0.7099^{\text {ns }}$ & $0.7544^{\text {ns }}$ & $0.6291^{\text {ns }}$ & $0.646^{\text {ns }}$ & $0.9832^{\text {ns }}$ & $0.7629^{\text {ns }}$ \\
TxDxF & $0.6331^{\text {ns }}$ & $0.8278^{\text {ns }}$ & $0.1746^{\text {ns }}$ & $0.1607^{\text {ns }}$ & $0.2589^{\text {ns }}$ & $0.3552^{\text {ns }}$ & $0.3404^{\text {ns }}$ & $0.6421^{\text {ns }}$ & $0.1591^{\text {ns }}$ \\
\hline CV $(\%)$ & 0.32 & 36.15 & 2.03 & 3.25 & 4.14 & 76.65 & 23.28 & 9.90 & 12.11 \\
\hline CM & $715.86 \mathrm{~b}$ & $7.38 \mathrm{~b}$ & $96.49 \mathrm{~b}$ & $\#$ & - & - & $\#$ & - & $18.87 \mathrm{~b}$ \\
SM & $828.03 \mathrm{a}$ & $8.27 \mathrm{a}$ & $100.09 \mathrm{a}$ & $\#$ & - & - & $\#$ & - & $21.58 \mathrm{a}$ \\
\hline CV
\end{tabular}

$\mathrm{CV}$ : coefficient of variation; SV: source of variation; $\mathrm{P}$ value: probability of difference between treatments and interactions; $* *$, significant at the 1 and $5 \%$ probability level $(\mathrm{p}<0.01$ and $\mathrm{p}<0.05)$, respectively; ns: not significant. \# Treatment with significative interaction. CM and SM: cattle and sheep biological fertilizer, respectively. Means followed by the same letter in the column do not differ by $\mathrm{F}$ test.

Table 2: Details of treatments as to the times and doses of application of biological fertilizers

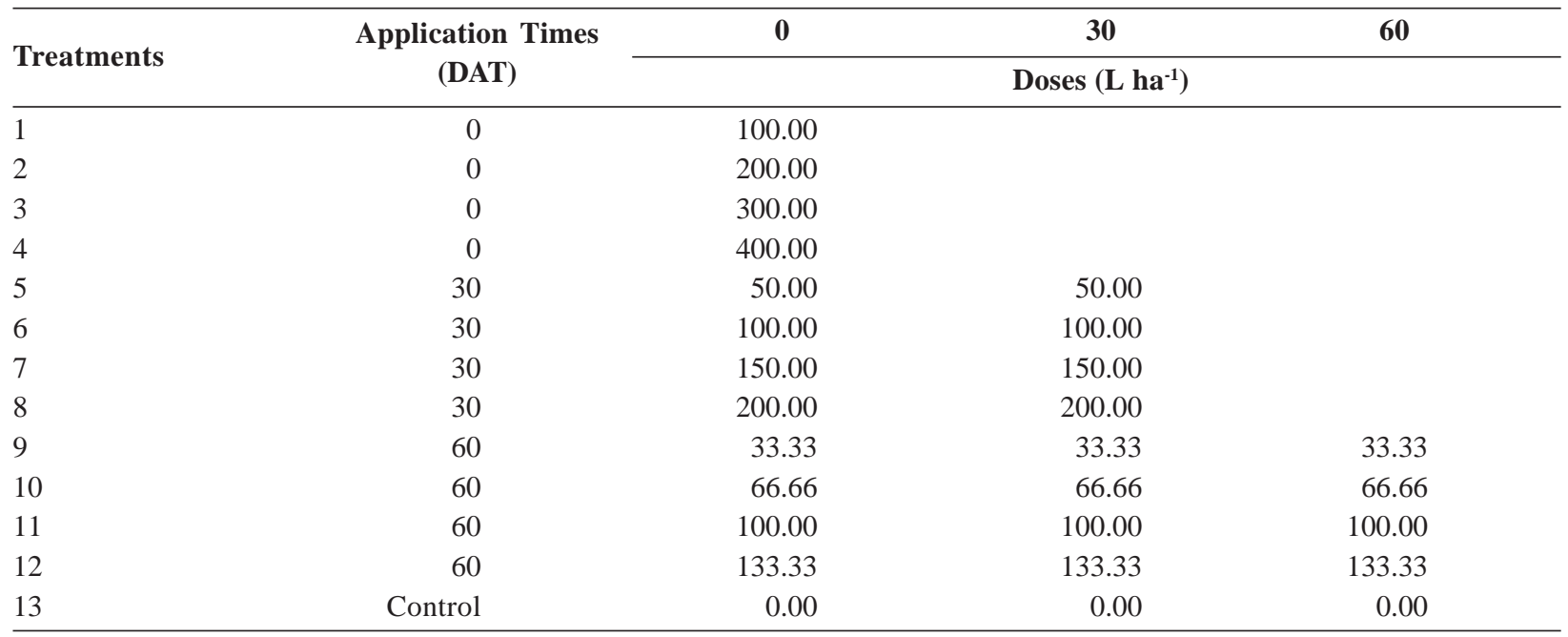

DAT $=$ days after transplantation

Rev. Ceres, Viçosa, v. 67, n.5, p. 374-382, sep/oct, 2020 
was performed: $\mathrm{pH}=6.7$; electrical conductivity $\left(\mathrm{dS} \mathrm{m} \mathrm{m}^{-1}\right)=$ $0.069 ; \mathrm{SO}_{4}^{-2}\left(\mathrm{mg} \mathrm{L}^{-1}\right)=0.00 ; \mathrm{Mg}^{+2}\left(\mathrm{mmol}_{\mathrm{c}} \mathrm{L}^{-1}\right)=0.18 ; \mathrm{Na}^{+}$ $\left(\mathrm{mmol}_{\mathrm{c}} \mathrm{L}^{-1}\right)=0.20 ; \mathrm{K}^{+}\left(\mathrm{mmol} \mathrm{L}_{\mathrm{c}} \mathrm{L}^{-1}\right)=0.10 ; \mathrm{Ca}^{+2}\left(\mathrm{mmol} \mathrm{L}_{\mathrm{c}} \mathrm{L}^{-1}\right)=$ $0.10 ; \mathrm{CO}_{3}^{-2}\left(\mathrm{mmol}_{\mathrm{c}} \mathrm{L}^{-1}\right)=0.00 ; \mathrm{HCO}_{3}^{-2}\left(\mathrm{mmol}_{\mathrm{c}} \mathrm{L}^{-1}\right)=1.20 ; \mathrm{Cl}$ $\left(\mathrm{mmol}_{\mathrm{c}} \mathrm{L}^{-1}\right)=0.30$; sodium adsorption ratio $\left(\mathrm{mmol}_{\mathrm{c}} \mathrm{L}^{-1}\right)=$ 0.60 ; exchangeable sodium percentage $\left(\mathrm{mmol}_{\mathrm{c}} \mathrm{L}^{-1}\right)=0.00$; classification $=\mathrm{C}_{1} \mathrm{~S}_{1}$ (Richards, 1954).

\section{Measured variables}

The total fruit weight per plant (TFW - expressed in g), weighing all fruits harvested on the plant, using a digital scale, was evaluated. The number of commercial fruits per plant $(\mathrm{NCF})$ was evaluated counting the number of fruits harvested per plant. The number of non-commercial fruits per plant (NNCF) was evaluated counting in the fruits that were not yet present at the point of harvest. The average fruit weight per plant (AFW - expressed in g) was evaluated dividing the TFW by the NCF. The fruit diameter (FD - expressed in $\mathrm{mm}$ ) was evaluated by measuring the with the aid of a digital caliper. The fruit length (FL - expressed in $\mathrm{cm}$ ) was evaluated measuring the longest fruit length. The fruit peel resistance (FPR) was evaluated using an analogic penetrometer (model GY3 , Luzeren ${ }^{\circledR}$ ). The number of flower buds (NFB) was evaluated counting the number of flowers per plant. The productivity ( $\mathrm{P}$ - expressed in $\mathrm{t} \mathrm{ha}^{-1}$ ) was evaluated estimating the yield per hectare using the total fruit weight per plant. In order to obtain the values of each variable mentioned above, the data averages of five harvests performed at 59, 66, 73, 80 and 87 DAT were calculated.

\section{Statistical analysis}

Data averages for the first five harvests were subjected to the normality (Shapiro-Wilk) and homogeneity (Bartlett) tests and then subjected to analysis of variance. When significant differences by the F test, the average test was performed (Tukey test up to $5 \%$ probability) for qualitative factors (biological fertilizers) and regression analysis for quantitative one (doses and application times). To compare factor combinations with additional treatment, the Dunnet test at $5 \%$ probability was performed. The statistical program used was R (R Core Team, 2018) and ExpDes (Ferreira et al., 2018) and multcomp (Hothorn et al., 2008) packages.

\section{RESULTS AND DISCUSSION}

Differences were observed between the biological fertilizers for total fruit weight per plant (TFW), number of commercial fruit per plant (NCF), average fruit weight $(\mathrm{AFW})$ and productivity $(\mathrm{P})$. Interactions were observed between application times and doses of biological fertilizers and between application times and biological fertilizers for fruit diameter (FD). The number of non- commercial fruits per plant (NNCF) had interaction between application times and biological fertilizers. The average fruit length (FL), fruit peel resistance (FPR), the number of flower buds (NFB) did not differ among biological fertilizers, doses, and application times (Table 1).

Biological fertilizer with sheep manure provided better results for the TFW (828.03 g), NCF (8.27), AFW (100.09 g) and $\mathrm{P}\left(21.58 \mathrm{t} \mathrm{ha}^{-1}\right)$. This was due to biological fertilizer has caused greater benefits to the soil and to the decomposing microorganisms, promoting greater availability of nutrients to the plants and consequently higher productive performance.

The TFW was $13.55 \%$ higher in bell pepper plants fertilized with sheep manure. The TFW an NCF of four bell pepper cultivars grown in organic production system was 19.6 tha-1 and 8.6 fruits, respectively (Negretti et al., 2010). It was $9.2 \%$ lower than the obtained in the sheep manure in this present study.

Bell pepper hybrids grown in conventional and organic cultivation systems had NCF and TFW of 3.29 and 331.56 $\mathrm{g}$ in the conventional system 3.0 and $367.24 \mathrm{~g}$ in the organic system, respectively (Pimenta et al., 2016). According these authors, the two systems evaluated had values below those observed in this study, demonstrating once again that the cultivation of peppers under biological fertilization has better results, probably by multiple benefits added to the soil and therefore the plants.

The AFW of bell pepper grown in the conventional cultivation system was $101.44 \mathrm{~g}$ and in organic system was $101.92 \mathrm{~g}$ (Pimenta et al., 2016), results close to that obtained in present study $(100.00 \mathrm{~g})$. It means that the $\mathrm{AFW}$ is similar in the management adopted in the cultivation of the bell pepper; however, the application of biological fertilizers provides greater fruit production, leading to the higher TFW and consequently the higher P.

The application of swine manure biofertilizer in two bell pepper cultivars increased the yield for Rubia cultivar (21.45 $\left.\mathrm{t} \mathrm{ha}^{-1}\right)$ and for Amanda cultivar (17.22 $\left.\mathrm{t} \mathrm{ha}^{-1}\right)$ (Sediyama et al., 2014). The average yield of this study was $21.58 \mathrm{t} \mathrm{ha}^{-1}$ for sheep manure, similar to that found in Rubia cultivar, and 18.87 t ha $^{-1}$ for cattle manure. Despite the similarity between the values, the volume of biological fertilizers applied in this work (100 to $400 \mathrm{~L} \mathrm{ha}^{-1}$ ) is much lower than the one applied by the authors $\left(120 \mathrm{~m}^{3} \mathrm{ha}^{-1}\right)$, which implies a lower need for labor and inputs, directly influencing the cost of production.

Application of liquid biofertilizers increased the fruit mass of aji pepper (Oliveira et al., 2014). This was due to nutritional properties, derived from the decomposition of organic matter, which stimulate the soil microbiological community, promoting greater nutrient availability for plants and improving soil physical characteristics, resulting in higher crop yield. 

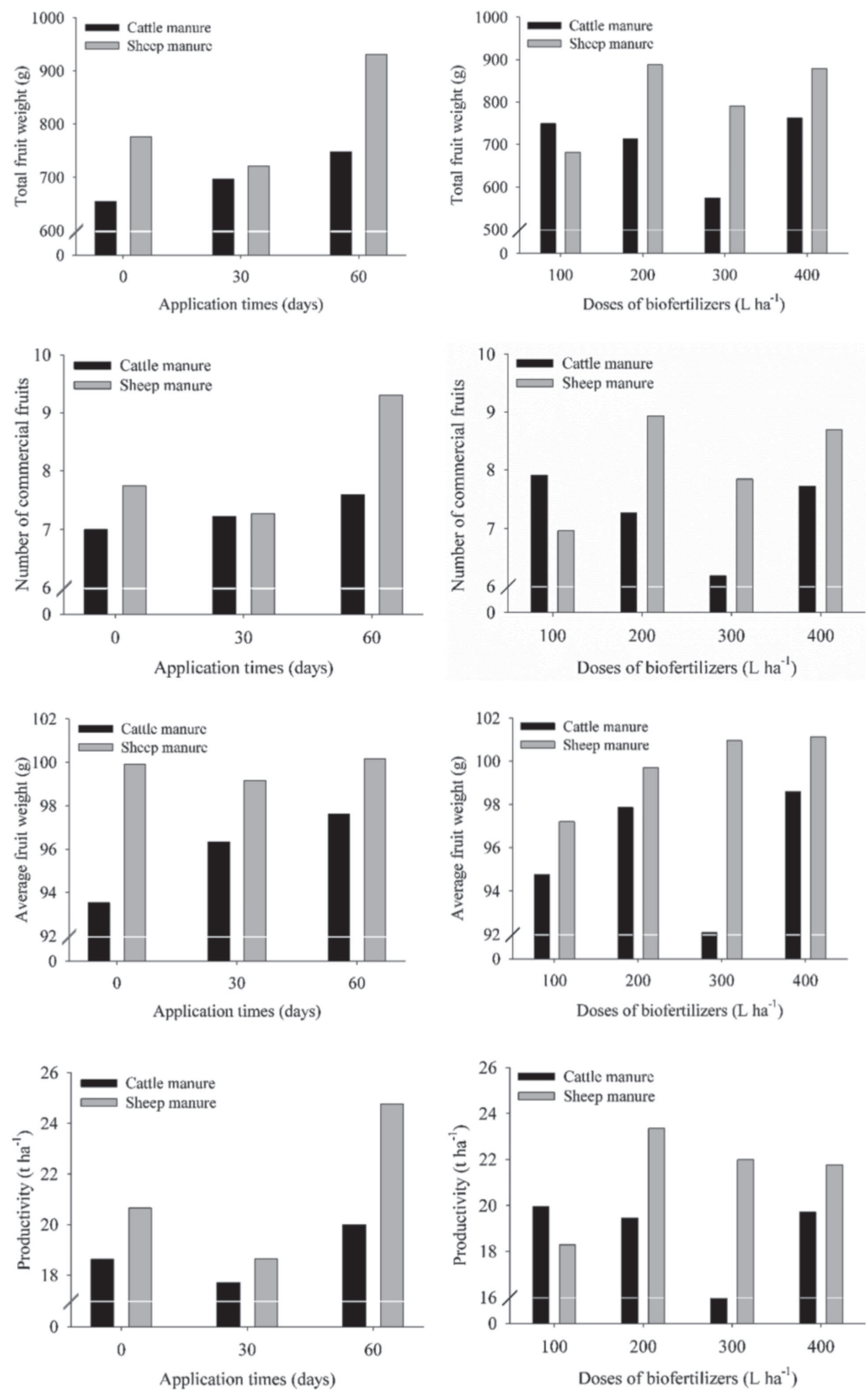

Figure 2: Total fruit weight, number of commercial fruits, average fruit weight and productivity of bell pepper fruits under biological fertilizers, doses and application times. 
The productivity of pumpkin fruits increased with application of swine biofertilizer (Santos et al., 2012). The largest production passion fruit production under irrigation with saline water was observed in plants that have been fertilized with biofertilizer due to the higher biological activity in the soil and adequate nutrient availability from biological fertilizer (Dias et al., 2011).

Interactions were observed for fruit diameter between application times and doses of biological fertilizers and between application times and biological fertilizers (Figure 3A). The largest fruit diameter $(7.64 \mathrm{~cm})$ was observed in bell pepper plants fertilized with cattle manure at the time of application 60 days. Sheep manure was higher than cattle manure only at the time of application 30 days. There was a difference only for the application time 30 days in relation to the doses of biofertilizers (Figure 3B). Interactions were observed for number of non-commercial fruits, difference was observed only in the application time 0 days. The largest number of non-commercial fruits (14.28 fruits) was observed in plants fertilized with cattle manure (Figure 3C). This result is congruent, since the highest number of commercial fruit was obtained with sheep manure, variable that considers the fruits harvested. As for the time of application, it can be justified due to the greater distance in days between the application of biological fertilizers and the harvesting period, reducing their effectiveness in providing higher number of commercial fruit.

Interaction between doses and times of application of suine biofertilizer (Sediyama et al., 2014), as in the present study. The largest fruit diameter $(6.28 \mathrm{~cm}) \mathrm{o}$ and fruit length $(15.05 \mathrm{~cm})$ was observed in bell pepper (Lopes et al., 2018), stating that these are attributes of economic importance, as they are evaluated by consumers, influencing the attractiveness of the fruits, the choice and consequently the purchase of bell pepper.
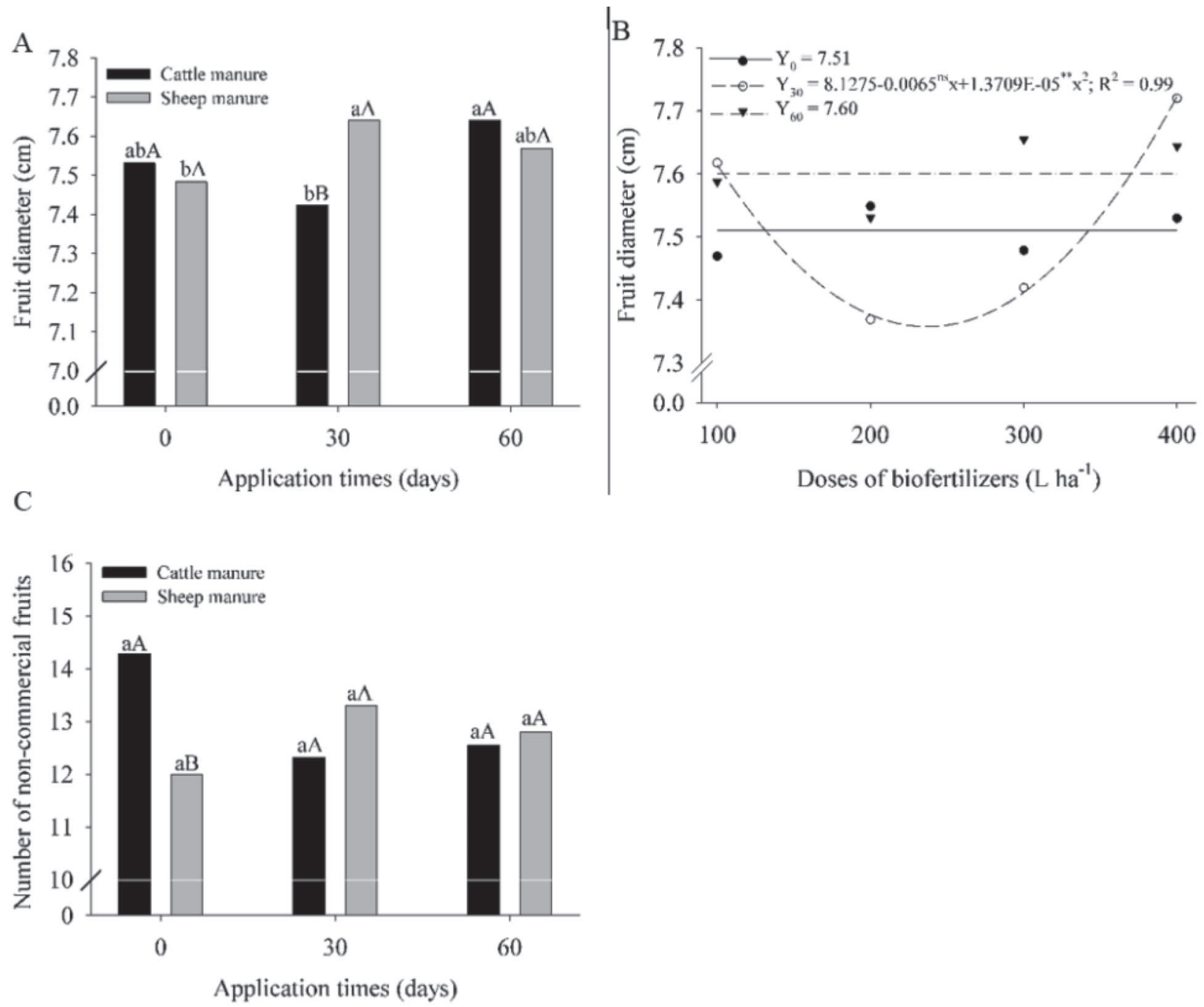

Figure 3: Interactions between application times and doses of biological fertilizers (A) and between application times and biological fertilizers (B) for stem diameter and interaction between application times and doses of biological fertilizers (C) for number of noncommercial fruits of bell pepper. Means followed by capital letters between biological fertilizers and lower case letters between application times do not differ by the Tukey test. 

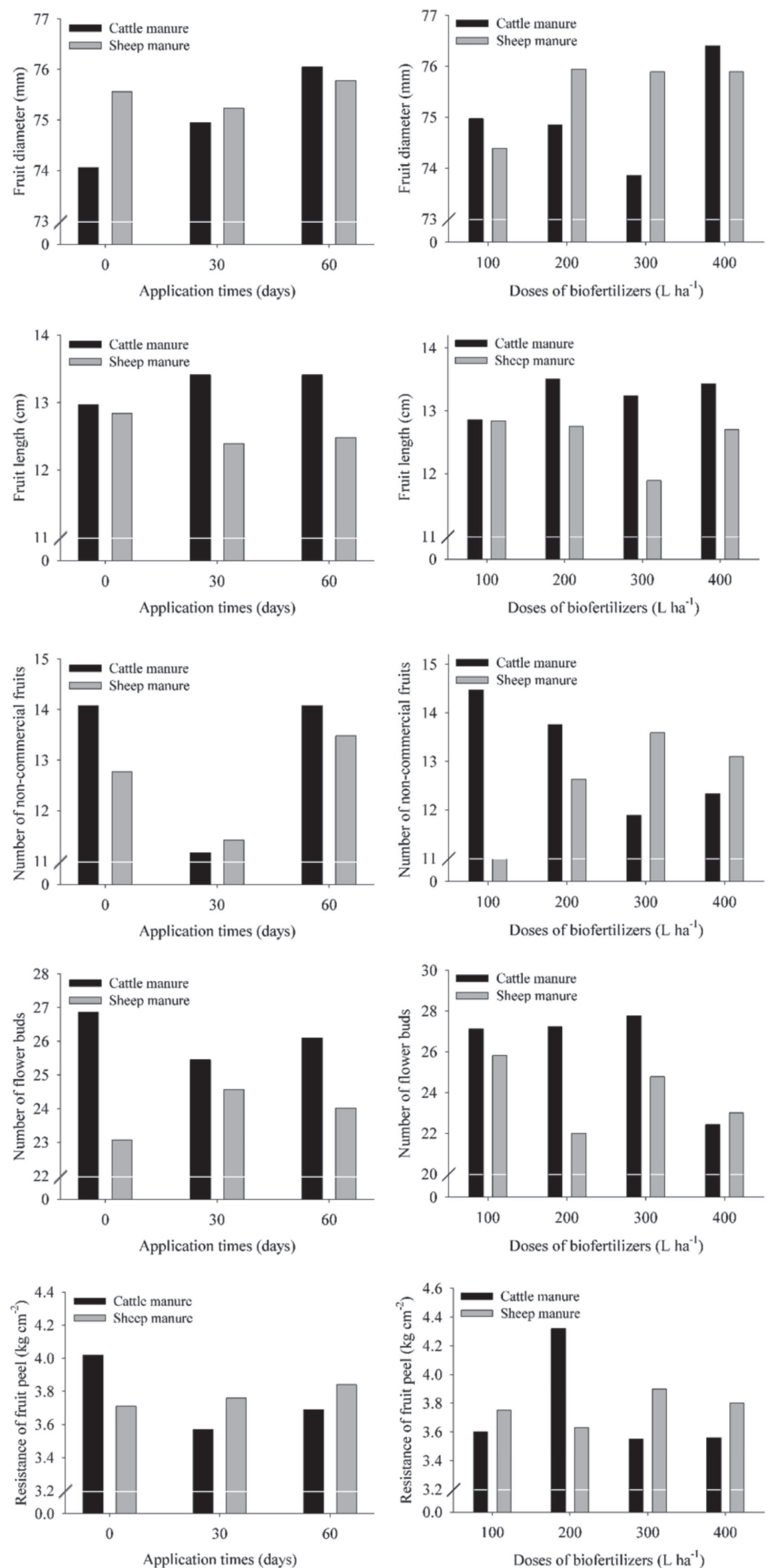

Figure 4: Fruit diameter, fruit length, number of non-commercial fruits, number of flower buds and fruit peel resistance of bell pepper under biological fertilizers, doses and application times. 
The largest fruit diameter $(7.51 \mathrm{~cm})$ of Solario hybrid was observed in the conventional cultivation system compared to the organic cultivation system $(7.79 \mathrm{~cm})$, justified by the greater aptitude of the hybrid (Pimenta $e t$ al., 2016). The average fruit diameter of three bell pepper cultivars grown under alternative substrates had of 6.4 cm at 74 DAT (Hachmann et al., 2017), showing that the substrates did not increase fruit development.

The biological fertilizers, doses and times of application had no significant differences for fruit lenght, fruit peel resistance and number of flower buds (Figure 4), probably due to the variety used to present great uniformity for these attributes, keeping close the respective values of each plant. In organic cultivation system, the Solário hybrid bell pepper obtained fruit lenght of $7.86 \mathrm{~cm}$ and in conventional cultivation of $7.52 \mathrm{~cm}$ (Pimenta et al., 2016). No effects found on fruit peel resistance and fruit length of bell pepper cultivated in organic system under fertilization with seaweed (Sá, 2014).

Comparing all treatments with the control by the Dunnett test at $5 \%$ probability, it was observed that the average fruit weight, fruit length and fruit peel resistance had a positive effect on applied biological fertilizers (Figure 5). No differences were observed for the other variables, so the graphs are not shown. For average fruit weight, the treatment 8 (30 days and dose $400 \mathrm{~L} \mathrm{ha}^{-1}$ ) of the sheep manure had greater results than the control. For fruit length and fruit peel resistance, the treatments 7 (30 days and 300 $\mathrm{L} \mathrm{ha}^{-1}$ dose) and 11 (60 days and $300 \mathrm{~L} \mathrm{ha}^{-1}$ dose) of cattle manure had the best results than the control.
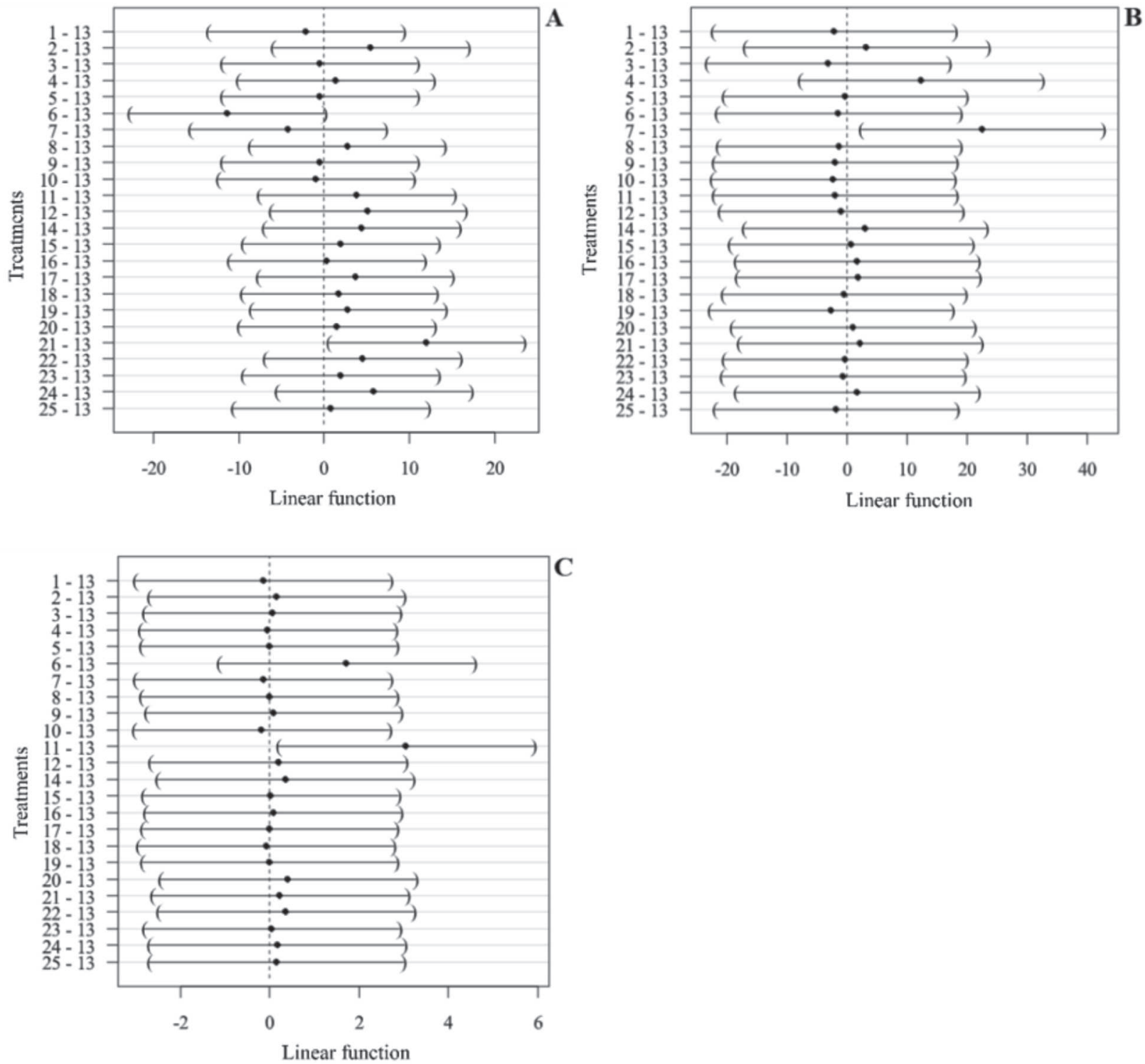

Figure 5: Dunnett test for average fruit weight (A), fruit length (B) and bell pepper peel resistance (C) under biological fertilizers, doses and application times. Treatments 1 to 12: referring to the experiment with cattle manure; treatments 14 and 25: referring to the sheep manure; 13: control. 


\section{CONCLUSIONS}

Organic fertilizers have positive effects on total fruit weight, number of commercial fruits, average fruit weight and bell pepper yield. The $300 \mathrm{~L} \mathrm{ha}^{-1}$ dose at 30 days after transplantation (DAT) promotes a significant increase in the diameter of bell pepper fruits. The application of cattle biological fertilizer at 60 DAT and the sheep biological fertilizer at 30 DAT promotes a larger diameter of bell pepper fruits. The average fruit weight, fruit length and fruit peel strength are influenced by the doses and application times of biological fertilizers. The application of biofertilizers is efficient in the production of bell pepper.

\section{ACKNOWLEDGEMENTS, FINANCIAL SUPPORT AND FULL DISCLOSURE}

The Coordination for the Improvement of Higher Education Personnel (CAPES - Coordenação de Aperfeiçoamento de Pessoal de Nível Superior) for granting scholarships to the first author and Irrigated Perimeter Apolônio Sales, for the area section and logistical support for the research. The authors declare that have no conflicts of interest.

\section{REFERENCES}

Alvares CA, Stape JL, Sentelhas PC, Gonçalves JLM \& Sparovek G (2014) Köppen's climate classification map for Brazil. Meteorologische Zeitschrift, 22:711-728.

Bertollo GM (2015) Atributos biológicos e físicos do solo com uso de biofertilizante. Dissertação de Mestrado. Universidade Federal de Santa Maria, Frederico Westphalen. 84p.

Celedonio CA, Medeiros JF, Viana TVA, Saraiva KR \& Lima GHP (2016) Área foliar da figueira em três ambientes de cultivo, sob fertirrigação de biofertilizante bovino. Revista Brasileira de Agricultura Irrigada, 10:586-597.

Chiconato DA, Simoni F, Galbiatti JA, Franco CF \& Caramelo AD (2013) Resposta da alface à aplicação de biofertilizante sob dois níveis de irrigação. Bioscience Journal, 29:392-399.

Dias TJ, Cavalcante LF, Leon MJ, Santos GP \& Albuquerque RPF (2011) Produção do maracujazeiro e resistência mecânica do solo com biofertilizante sob irrigação com águas salinas. Revista Ciência Agronômica, 42:644-651.

Ferreira EB, Cavalcanti PP \& Nogueira DA (2018) Package 'ExpDes.pt': Experimental Designs. R package version 1.2.0. Available at: https://cran.r-project.org/web/packages/ExpDes.pt/ ExpDes.pt.pdf. Accessed on: October 11 ${ }^{\text {th }}, 2019$.

Guimarães NF, Gallo AS, Fontanetti A, Meneghin SP, Souza MDB, Morinigo KPG \& Silva RF (2017) Biomassa e atividade microbiana do solo em diferentes sistemas de cultivo do cafeeiro. Revista de Ciências Agrárias, 40:34-44.

Hachmann TL, Dalastra GM, Echer MM, Lozano CS \& Rezende R (2017) Características produtivas de duas cultivares de pimentão em substratos alternativos. Cultura Agronômica, 26:502-513.

Hothorn T, Bretz F \& Westfall P (2008) Simultaneous Inference in General Parametric Models. Biometrical Journal, 50:346363.
Lopes SM, Alcantra E, Rezende RM \& Freitas AS (2018) Avaliação de frutos de pimentão submetidos ao ensacamento no cultivo orgânico. Revista da Universidade Vale do Rio Verde, 16:0111.

Microgeo (2019) Manual técnico. Microgeo - Adubação biológica. Available at: http://microgeo.com.br/site/front/img/ manual_tecnico.pdf. Accessed on: February13 $3^{\text {th }}, 2019$.

Negretti RRD, Bini DA, Amaral U \& Martins CR (2010) Avaliação da adubação orgânica em pimentão Capsicun annuum cultivado em sistema orgânico de produção sob ambiente protegido. Revista da Faculdade de Zootecnia Veterinária e Agronomia, 17:27-37.

Oliveira JR, Gomes RLF, Araújo ASF, Marini SF, Lopes JB \& Araújo RM (2014) Estado nutricional e produção da pimenteira com uso de biofertilizantes líquidos. Revista Brasileira de Engenharia Agrícola e Ambiental, 18:1241-1246.

Parahyba R, Silva FHBB, Silva F, Araujo Filho JC, Lopes PRC \& Silva DF (2004) Diagnóstico agroambiental do Município de Petrolândia - Estado de Pernambuco. Recife, Embrapa Solos. 25p. (Circular Técnica, 29).

Pimenta S, Menezes D, Neder DG, Melo RA, Araujo ALR \& Maranhão EAA (2016) Adaptability and stability of pepper hybrids under conventional and organic production systems. Horticultura Brasileira, 34:168-174.

R Development Core Team (2018) R: A language and environment for statistical computing. Vienna, R Foundation for Statistical Computing. 2673p.

Richards LA (1954) Diagnosis and improvement of saline and alkali soils. Washington, USDA. 160p.

Sá ARM (2014) Irrigação e adubação com lithothamnium no cultivo de pimentão orgânico. Dissertação de Mestrado. Universidade Federal de Goiás, Goiânia. 62p.

Santos TT, Chagas AB, Santos JKB, Santos E \& Barros RP (2018) Estudo do desenvolvimento fenológico de duas gerações do Pimentão All Big (Capsicum annuum L.) plantados em vasos. Diversitas Journal, 3:539-548.

Santos PR, Moura FM, Alves AO, Rocha FAT, Rodrigues JD, Filho FP \& Menezes D (2013) Avaliação de híbridos simples e triplos de pimentão em ambiente protegido. In: XIII Jornada de Ensino Pesquisa e Extensão Universidade Federal Rural de Pernambuco, Recife. Anais, UFRPE. p.01-03.

Santos MR, Sediyama MAN, Moreira M, Megguer CA \& Vidigal SM (2012) Rendimento qualidade e absorção de nutrientes pelos frutos de abóbora em função de doses de biofertilizante. Horticultura Brasileira, 30:160-167.

Santos HG, Jacomine PKT, Anjos LHC, Oliveira VA, Oliveira JD, Coelho MR, Lumbreras JF \& Cunha TJF (2006) Sistema brasileiro de classificação de solos. $2^{\mathrm{a}}$ ed. Rio de Janeiro, Embrapa Solos. 306p.

Sediyama MAN, Marlei RS, Vidigal SM, Pinto CLO \& Jacob LL (2014) Nutrição e produtividade de plantas de pimentão colorido adubadas com biofertilizante de suíno. Revista Brasileira de Engenharia Agrícola e Ambiental, 18:588-594. 